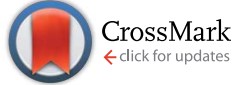

Cite this: RSC Adv., 2015, 5, 84999

Received 21st August 2015

Accepted 29th September 2015

DOI: $10.1039 / c 5 r a 16900 c$

www.rsc.org/advances

\section{A Raman spectroscopic investigation of speciation in $\mathrm{La}_{2}\left(\mathrm{SO}_{4}\right)_{3}(\mathrm{aq}) \uparrow$}

\author{
Wolfram W. Rudolph*a and Gert Irmer
}

Raman spectroscopic measurements have been made of aqueous solutions of $\mathrm{La}\left(\mathrm{ClO}_{4}\right)_{3}, \mathrm{La}_{2}\left(\mathrm{SO}_{4}\right)_{3}$, and $\mathrm{Na}_{2} \mathrm{SO}_{4}$ in water and heavy water, in the terahertz frequency region $\left(40-1400 \mathrm{~cm}^{-1}\right)$ and down to low concentrations $\left(0.000263 \mathrm{~mol} \mathrm{~L}{ }^{-1}\right)$. Temperature dependent measurements of a $0.0098 \mathrm{~mol} \mathrm{~L}^{-1}$ $\mathrm{La}_{2}\left(\mathrm{SO}_{4}\right)_{3}$ solution have been carried out from $23-98{ }^{\circ} \mathrm{C}$. In solutions of $\mathrm{La}\left(\mathrm{ClO}_{4}\right)_{3}$ with water and heavy water, the $\left[\mathrm{La}\left(\mathrm{OH}_{2}\right)_{9}\right]^{3+}$ and $\left[\mathrm{La}\left(\mathrm{OD}_{2}\right)_{9}\right]^{3+}$ have been characterized and a weak, strongly polarized band observed at $343 \mathrm{~cm}^{-1}$ and $326 \mathrm{~cm}^{-1}$ respectively assigned to the $\nu_{1} \mathrm{LaO}_{9}$ mode, the breathing mode of the clusters. In $\mathrm{La}_{2}\left(\mathrm{SO}_{4}\right)_{3}(\mathrm{aq})$, in addition to the $\nu_{1}-\mathrm{SO}_{4}{ }^{2-}$ mode at $980 \mathrm{~cm}^{-1}$, a pronounced band component at $991 \mathrm{~cm}^{-1}$ has been assigned to an inner-sphere complex (ISC) and a similar $\nu_{1}-\mathrm{SO}_{4}{ }^{2-}$ band contour has been observed in $\mathrm{La}_{2}\left(\mathrm{SO}_{4}\right)_{3}$ solutions in $\mathrm{D}_{2} \mathrm{O}$. Sulfate may act as a monodentate ligand. Conformation of this assignment is provided by the component at $312 \mathrm{~cm}^{-1}$ of the $\left[\mathrm{La}\left(\mathrm{OH}_{2}\right)_{8} \mathrm{OSO}_{3}\right]^{+}$ species in addition to the band at $343 \mathrm{~cm}^{-1}$ for the fully hydrated cluster, $\left[\mathrm{La}\left(\mathrm{OH}_{2}\right)_{9}\right]^{3+}$. After subtraction of the component of the ISC at $991 \mathrm{~cm}^{-1}$, the $\nu_{1}-\mathrm{SO}_{4}{ }^{2-}$ band in $\mathrm{La}_{2}\left(\mathrm{SO}_{4}\right)_{3}(\mathrm{aq})$ showed systematic differences from that in $\mathrm{Na}_{2} \mathrm{SO}_{4}(\mathrm{aq})$. This is consistent with a $\nu_{1}-\mathrm{SO}_{4}{ }^{2-}$ band at $983.3 \mathrm{~cm}^{-1}$ that can be assigned to the existence of an outer-sphere complex (OSCs). The observed change of the degree of sulfato-complex formation with dilution reflects the stepwise sulfato-complex formation. A $K_{3}$-value has been determined at 0.9 of the equilibrium between OSC and ISC. Temperature dependent measurements on a dilute $\mathrm{La}_{2}\left(\mathrm{SO}_{4}\right)_{3}$ solution has shown that the concentration of the $\mathrm{La}^{3+}$ sulfatocomplex rises with increasing temperature while at the same time the concentration of the "free" sulfate diminished. The sulfato-complex formation is an endothermic process absorbing heat with increasing temperature. The following thermodynamic parameters for the rate determining equilibrium, $\left[\mathrm{La}\left(\mathrm{OH}_{2}\right)\right.$ $\left.\mathrm{SO}_{4}\right]^{+} \leftrightarrow\left[\mathrm{LaOSO}_{3}\right]^{+}$has been determined: $\Delta H^{0}=18.6 \mathrm{~kJ} \mathrm{~mol}^{-1}$ and $\Delta S^{0}=62.1 \mathrm{~J} \mathrm{~mol}^{-1} \mathrm{~K}^{-1}$.

\section{Introduction}

Lanthanum sulfate enneahydrate, $\mathrm{La}_{2}\left(\mathrm{SO}_{4}\right)_{3} \cdot 9 \mathrm{H}_{2} \mathrm{O}$, is the most common hydrate of lanthanum sulfate, $\mathrm{La}_{2}\left(\mathrm{SO}_{4}\right)_{3} \cdot n \mathrm{H}_{2} \mathrm{O}(n=1-$ 9) ${ }^{1-3}$ and is the only stable hydrate in contact with its solution between $0^{\circ}$ and $100^{\circ} . \mathrm{La}_{2}\left(\mathrm{SO}_{4}\right)_{3}$ is sparingly soluble at room temperature and the solubility diminishes with temperature. Lanthanum exists in aqueous solution exclusively in the trivalent state and the $\mathrm{La}^{3+}$ ion is strongly hydrated due to its high charge to radius ratio. The coordination number $(\mathrm{CN})$ in the primary hydration shell for $\mathrm{La}^{3+}$ in aqueous solution has been determined at nine (data in Table 1, ref. 4). The water molecules of the nonahydrate results in a hydration structure of a tricapped trigonal prism (TTP) with $D_{3}$ symmetry. ${ }^{5}$ The O-atoms of the three waters in the equatorial plane (capping position) are

${ }^{a}$ Medizinische Fakultät der TU Dresden, Institut für Virologie im MTZ, Fiedlerstr. 42, 01307 Dresden, Germany. E-mail: Wolfram.Rudolph@tu-dresden.de

${ }^{b}$ Technische Universität Bergakademie Freiberg, Institut für Theoretische Physik, Leipziger Str. 23, 09596 Freiberg, Germany

$\dagger$ Electronic supplementary information (ESI) available. See DOI: $10.1039 / \mathrm{c} 5 \mathrm{ra} 16900 \mathrm{c}$ separated from the cation by a bond distance of $2.64 \AA$, while six water molecules at the vertices of the trigonal prism have a $\mathrm{La}-\mathrm{O}$ bond distance of $2.515 \AA .^{5,6}$ A recent Raman spectroscopic investigation revealed that in concentrated $\mathrm{La}\left(\mathrm{ClO}_{4}\right)_{3}(\mathrm{aq})$ ion pairs are formed while in dilute solutions the undisturbed $\left[\mathrm{La}\left(\mathrm{H}_{2} \mathrm{O}\right)_{9}\right]^{3+}$ species exist.

This study has been undertaken to characterize the species formed in aqueous $\mathrm{La}^{3+}$-sulfate solutions over a very broad concentration range and at elevated temperatures. Sulfatocomplex formation has been characterized in solutions on a variety of divalent and trivalent metal sulfates ${ }^{7-12}$ and the question arises whether these complexes also occur with $\mathrm{La}^{3+}(\mathrm{aq})$. The investigation of $\mathrm{La}_{2}\left(\mathrm{SO}_{4}\right)_{3}$ solutions proved to be especially challenging because lanthanum sulfate is only sparingly soluble in water and the salt shows a retrograde solubility with temperature increase. The study on the aqueous $\mathrm{La}_{2}\left(\mathrm{SO}_{4}\right)_{3}$ is the first Raman experimental investigation one this dilute system. The following aqueous systems have been measured using Raman spectroscopy at $23{ }^{\circ} \mathrm{C}: \mathrm{La}\left(\mathrm{ClO}_{4}\right)_{3}, \mathrm{La}_{2}\left(\mathrm{SO}_{4}\right)_{3}$ and $\mathrm{Na}_{2} \mathrm{SO}_{4}$. Specifically, we have been interested in the vibrational characterization of the $\mathrm{La}^{3+}$-aqua stretching band at low 
concentration and the possible formation of ion pairs/ complexes between $\mathrm{La}^{3+}$ and sulfate. Dilute $\mathrm{Na}_{2} \mathrm{SO}_{4}$ solutions have been measured to characterize the sulfate modes free of sulfato-complex species. A $\mathrm{La}_{2}\left(\mathrm{SO}_{4}\right)_{3}$ solution at $0.0098 \mathrm{~mol} \mathrm{~L}^{-1}$ has been measured from $23{ }^{\circ} \mathrm{C}$ to $98{ }^{\circ} \mathrm{C}$ in order to characterize the sulfato-complex formation as a function of temperature. Thermodynamic parameters such as enthalpy and entropy of the sulfato-complex formation have been determined from the measured $K_{3}$ values as a function of temperature.

\section{Experimental details}

\subsection{Preparation of solutions}

Lanthanum perchlorate solutions were prepared from $\mathrm{La}_{2} \mathrm{O}_{3}$ (Sigma-Aldrich, 99.9\%) and $\mathrm{HClO}_{4}$ in a beaker until all oxide dissolved. The lanthanum ion content was analysed by complexometric titration. ${ }^{13}$ The solution density was determined with a pycnometer at $23{ }^{\circ} \mathrm{C}$ and the molar ratios water per salt were calculated $\left(R_{\mathrm{w}}\right.$-values). $\mathrm{A} \mathrm{La}\left(\mathrm{ClO}_{4}\right)_{3}$ stock solution was prepared at $2.488 \mathrm{~mol} \mathrm{~L}^{-1}\left(R_{\mathrm{w}}=15.72\right)^{4}$ and the solution was slightly acidic with a $\mathrm{pH}$ value at $\sim 3.5$. From the stock solution, the following dilution series was prepared: $0.622 \mathrm{~mol} \mathrm{~L}^{-1}\left(R_{\mathrm{w}}=\right.$ 81.54), $0.498 \mathrm{~mol} \mathrm{~L}^{-1}\left(R_{\mathrm{W}}=103.43\right)$ and $0.249 \mathrm{~mol} \mathrm{~L}^{-1}\left(R_{\mathrm{W}}=\right.$ 213.75). The solutions were analyzed for dissolved chloride with a $5 \% \mathrm{AgNO}_{3}$ solution. The absence of a white $\mathrm{AgCl}$ precipitate proved that the stock solution was free of $\mathrm{Cl}^{-}$. For Raman spectroscopic measurements the solutions were filtered through a fine sintered glass frit (1-1.6 $\mu \mathrm{m}$ pore size). The solutions showed no Tyndall effect and were "optically empty" (see e.g. ref. 14).

Lanthanum sulfate is only sparingly soluble in water. A $0.0376 \mathrm{~mol} \mathrm{~L}^{-1} \mathrm{La}_{2}\left(\mathrm{SO}_{4}\right)_{3}$ stock solution $\left(0.0378_{4} \mathrm{~mol} \mathrm{~kg}^{-1}\right)$ was prepared from $\mathrm{La}_{2}\left(\mathrm{SO}_{4}\right)_{3} \cdot 9 \mathrm{H}_{2} \mathrm{O}$ and was used to further prepare dilute solutions. The solution density of the stock solution and its $\mathrm{La}^{3+}$ were determined as described above. The $\mathrm{pH}$ of the stock solution was determined with a glass electrode equal to 5.52. Nine solutions were prepared from this stock solution: $0.0302 \mathrm{~mol} \mathrm{~L}^{-1}, 0.0189 \mathrm{~mol} \mathrm{~L}^{-1}, 0.0093 \mathrm{~mol} \mathrm{~L}^{-1}, 0.00754 \mathrm{~mol}$ $\mathrm{L}^{-1}, 0.00606 \mathrm{~mol} \mathrm{~L}^{-1}, 0.00377 \mathrm{~mol} \mathrm{~L}^{-1}, 0.00189 \mathrm{~mol} \mathrm{~L}^{-1}$, $0.00121 \mathrm{~mol} \mathrm{~L}^{-1}, 0.00094 \mathrm{~mol} \mathrm{~L}^{-1}$ and $0.00026 \mathrm{~mol} \mathrm{~L}^{-1}$. The lanthanum ion content was analysed by complexometric titration and the solution density was determined with a $5.000 \mathrm{~mL}$ pycnometer at $23{ }^{\circ} \mathrm{C}$.

\subsection{Spectroscopic measurements}

Raman spectra were measured in the macro chamber of the $\mathrm{T}$ 64000 Raman spectrometer from Jobin Yvon in a $90^{\circ}$ scattering geometry at $23{ }^{\circ} \mathrm{C}$. These measurements have been described elsewhere in detail. ${ }^{15,16}$ Briefly, the spectra were excited with the $514.5 \mathrm{~nm}$ line of an $\mathrm{Ar}^{+}$laser at a power level of $1100 \mathrm{~mW}$ at the sample. After passing the spectrometer in subtractive mode, with gratings of 1800 grooves per $\mathrm{mm}$, the scattered light was detected with a cooled CCD detector. $I_{\mathrm{VV}}$ and $I_{\mathrm{VH}}$ spectra were obtained with fixed polarisation of the laser beam by rotating the polarisator at $90^{\circ}$ between the sample and the entrance slit to give the scattering geometries:

$$
\begin{gathered}
I_{\mathrm{VV}}=I(Y[Z Z] X)=45 \alpha^{\prime 2}+4 \gamma^{\prime 2} \\
I_{\mathrm{VH}}=I(Y[Z Y] X)=3 \gamma^{\prime 2} .
\end{gathered}
$$

The isotropic spectrum, $I_{\text {iso }}$ is then constructed:

$$
I_{\text {iso }}=I_{\mathrm{VV}}-4 / 3 I_{\mathrm{VH}} \text {. }
$$

The depolarization ratio, $\rho$, of the modes were determined according to eqn (4):

$$
\rho=I_{\mathrm{VH}} / I_{\mathrm{VV}}=3 \gamma^{\prime 2} /\left(45 \alpha^{\prime 2}+4 \gamma^{\prime 2}\right) .
$$

The polarization analyser was calibrated with $\mathrm{CCl}_{4}$ before each measuring cycle and adjusted if necessary. The depolarisation ratio of the $\nu_{1}$ mode of $\mathrm{CCl}_{4}$ at $459 \mathrm{~cm}^{-1}$ was determined at $0.0036 \pm 0.0005$ (15 independent measurements). The depolarization ratios of the depolarized $\mathrm{CCl}_{4}$ bands at $217 \mathrm{~cm}^{-1}$ and $315 \mathrm{~cm}^{-1}$ have been determined at $0.75 \pm 0.02$.

In order to obtain spectra defined as $I(\bar{\nu})$ which are independent of the excitation wavenumber $\nu_{\mathrm{L}}$, the measured Stokes intensity should be corrected for the scattering factor $\left(\nu_{\mathrm{L}}-(\bar{\nu})\right)^{3}$. When counting methods are used, the measured count rates have to be corrected with the factor $\left(\nu_{\mathrm{L}}-(\bar{\nu})\right)^{3}$. The spectra were further corrected for the Bose-Einstein temperature factor, $B=$ $[1-\exp (-h \bar{\nu} c / k T)]$ and the frequency factor, $\bar{\nu}$, to give the so called reduced or $R(\bar{\nu})$ spectrum. It is also possible to calculate the isotropic spectrum in $R$-format from the corrected $R_{\mathrm{VV}}$ and $R_{\mathrm{VH}}$ spectra according to eqn (5):

$$
R(\bar{\nu})_{\text {iso }}=R(\bar{\nu})_{\mathrm{VV}}-4 / 3 R(\bar{\nu})_{\mathrm{VH}}
$$

In the low wavenumber region the $I(\bar{\nu})$ and $R_{\mathrm{Q}}(\bar{\nu})$ spectra are significantly different and only the spectra in $R$-format are presented. It should be noted that one of the advantages of using isotropic $R$-spectra is that the baseline is almost flat in the $50-700 \mathrm{~cm}^{-1}$ wavenumber region allowing relatively unperturbed observation of the presence of any weak modes. ${ }^{\mathbf{1 5 , 1 6}}$

The spectra were fitted to a sum of Lorentzian-Gaussian product functions and the fitting procedure has been described elsewhere in detail. ${ }^{\mathbf{1 7}}$

Temperature dependent Raman measurements were carried out in sealable fused quartz cuvettes, $10 \times 10 \mathrm{~mm}$, with $3.5 \mathrm{~mL}$ volume from Hellma (Müllheim, Germany) using a home-built oven. The oven and the setup have been described in detail in ref. 17.

\subsection{Quantitative Raman measurements of the sulfato complex formation}

In order to be able to quantify species in solution without using an internal standard, the relative molar scattering factors (RMSF) for those bands must be determined. ${ }^{18}$ The RMSF for $\nu_{1}$ $\mathrm{SO}_{4}{ }^{2-}$ at $980 \mathrm{~cm}^{-1}$ for "free" $\mathrm{SO}_{4}{ }^{2-}$ in $\left(\mathrm{NH}_{4}\right)_{2} \mathrm{SO}_{4}$ solutions were measured in solutions in which a known amount of $\mathrm{NH}_{4} \mathrm{ClO}_{4}$ had been dissolved as an internal standard $\left(\mathrm{ClO}_{4}{ }^{-}\right.$band $\nu_{1}$ at $931 \mathrm{~cm}^{-1}$ ). From the integrated band intensities, $A_{\mathrm{i}}$, and the concentration of the standard, the relative integrated band 
intensities, $I_{\mathrm{R}}$, with $I_{\mathrm{R}}=\left(A_{980} / A_{931}\right) C_{\mathrm{NH}_{4} \mathrm{ClO}_{4}}$ were calculated. The quantity $I_{\mathrm{R}}$ is directly proportional to the concentration of the species of interest and thus: $I_{\mathrm{R}}=J C$. From the slope of the curve, $I_{\mathrm{R}}=J C$, the so called relative molar scattering coefficient, $J$ was obtained. For $\nu_{1} \mathrm{SO}_{4}{ }^{2-}$ at $980 \mathrm{~cm}^{-1}$, it follows $J_{980}=0.788$ and for bound sulfate at $991 \mathrm{~cm}^{-1}: J_{991}=0.760$.

The equilibrium concentrations of $\left[\mathrm{SO}_{4}{ }^{2-}\right]_{\text {free }}$ and $\left[\mathrm{SO}_{4}{ }^{2-}\right]$ bound were obtained from the ratios of the areas of "free" $\mathrm{SO}_{4}{ }^{2-}$ mode at $980 \mathrm{~cm}^{-1}$ (this mode includes contributions from the fully hydrated sulfate, in the outer-outer-sphere and outer-sphere ${ }^{30-33}$ ) and the bound $\mathrm{SO}_{4}{ }^{2-}$ mode at $991 \mathrm{~cm}^{-1}$ and the relative molar scattering factors. The sum of the equilibrium concentrations $\left[\mathrm{SO}_{4}{ }^{2-}\right]_{\text {free }}$ plus $\left[\mathrm{SO}_{4}{ }^{2-}\right]_{\text {bound }}$ is equal to $C_{0}$, the stoichiometric concentration of $\mathrm{MnSO}_{4}$ (in mol kg${ }^{-1}$ ). The integrated band intensities are $A_{980}=J_{980}\left[\mathrm{SO}_{4}{ }^{2-}\right]_{\text {free }}$ and $A_{991}=$ $J_{991}\left[\mathrm{SO}_{4}{ }^{2-}\right]_{\text {bound }}=J_{991}\left(C_{0}-\left[\mathrm{SO}_{4}{ }^{2-}\right]_{\text {free }}\right)$, where $J_{980}$ and $J_{991}$ are the relative molar scattering factors for the bands at $\sim 980$ and $991 \mathrm{~cm}^{-1}$. For the ratio of the integrated intensities, $A_{980} / A_{991}$ was calculated as follows:

$$
\frac{A_{991}}{A_{980}}=\frac{J_{991}\left(C_{0}-\left[\mathrm{SO}_{4}{ }^{2-}\right]_{\text {free }}\right)}{J_{980}\left[\mathrm{SO}_{4}{ }^{2-}\right]_{\text {free }}}
$$

and after rearranging for $\left[\mathrm{SO}_{4}{ }^{2-}\right]_{\text {free }}$ it follows:

$$
\left[\mathrm{SO}_{4}{ }^{2-}\right]_{\text {free }}=\frac{C_{0}}{\frac{J_{980}}{J_{991}} \frac{A_{991}}{A_{980}}+1}
$$

With the equilibrium concentration of $\left[\mathrm{SO}_{4}{ }^{2-}\right]_{\text {free }}$ determined and $C_{0}$, the stoichiometric concentration of $\mathrm{La}_{2}\left(\mathrm{SO}_{4}\right)_{3}$ known, the degree of bound sulfate, $\alpha$, may be calculated by eqn (8):

$$
\alpha=\left(C_{0}-\left[\mathrm{SO}_{4}^{2-}\right]_{\text {free }}\right) / C_{0} .
$$

\section{Results and discussion}

\subsection{The unassociated $\left[\mathrm{La}\left(\mathrm{OH}_{2}\right)_{9}\right]^{3+}(\mathrm{aq})$}

The $\mathrm{La}^{3+}(\mathrm{aq})$ ion is strongly hydrated in aqueous solution due to its high charge to radius ratio. A recent DFT study on a $\left[\mathrm{Ln}\left(\mathrm{H}_{2} \mathrm{O}\right)_{9}\right]^{3+}$ cluster imbedded in a polarizable dielectric continuum, taking into account the bulk water resulted in a tricapped trigonal prism (TTP) polyhedron of symmetry $D_{3} \cdot{ }^{4}$ The oxygen atoms of three water molecules in the equatorial plane are separated from $\mathrm{La}^{3+}$ by a bond distance of $2.64 \AA$, while six water molecules at the vertices of the trigonal prism are found at an average La-O bond distance at $2.515 \AA \AA^{5,6}$ The hydration sphere of $\mathrm{La}^{3+}(\mathrm{aq})$ is labile and a water-exchange rate constant $k_{\text {ex }}$ at $25{ }^{\circ} \mathrm{C}$ was given at $\geq 2 \times 10^{8} \mathrm{~s}^{-1} \ddagger$ (estimated from $\mathrm{H}_{2} \mathrm{O}-\mathrm{SO}_{4}{ }^{2-}$ interchange rates) and a water residence time $\tau=\sim 5$ ns follows. ${ }^{19,20}$ Because of the labile coordination sphere for $\mathrm{La}^{3+}$ there is the possibility of a counterion (anion) coordination replacing water from the coordination polyhedron. ${ }^{21}$

\$ The datum for $k_{\text {ex }}$ at $25^{\circ} \mathrm{C}$ was given incorrectly in ref. 4 page 298 .
Although perchlorate is considered a non-complex forming anion, in $\mathrm{La}\left(\mathrm{ClO}_{4}\right)_{3}$ solutions at higher salt concentrations (1.5 mol L ${ }^{-1}$ ), it was shown that perchlorate forms outer sphere-ion pairs, $\left[\mathrm{La}\left(\mathrm{OH}_{2}\right)_{9}\right]^{3+} \cdot \mathrm{ClO}_{4}{ }^{-}$and at yet higher concentrations perchlorate penetrates into the first hydration sphere of the $\mathrm{La}^{3+} \cdot{ }^{4}$ In $\mathrm{La}\left(\mathrm{ClO}_{4}\right)_{3}(\mathrm{aq})$ at $2.488 \mathrm{~mol} \mathrm{~L}^{-1}$ the mole ratio solute to water is $\mathbf{1 5 . 7}$ and this amount of water is barely enough to completely hydrate the $\mathrm{La}^{3+}$ ion while the remaining 6.7 water molecules hydrate the three $\mathrm{ClO}_{4}{ }^{-}$ions. In such a concentrated solution contact ion pair formation is simply forced on $\mathrm{La}^{3+}$. Therefore, it is necessary to measure dilute $\mathrm{La}\left(\mathrm{ClO}_{4}\right)_{3}$ solutions but this measurement is hampered by the fact that the $\mathrm{La}-\mathrm{O}$ breathing mode is very weak and its Raman scattering coefficient, 0.030, is low.

A vibrational analysis of the $\mathrm{LaO}_{9}$ skeleton modes of the $\left[\mathrm{La}\left(\mathrm{OH}_{2}\right)_{9}\right]^{3+}$ species ( $D_{3 \mathrm{~h}}$ symmetry) has been carried out recently. ${ }^{4}$ Twenty four normal modes (n.m.'s) are expected for the $\mathrm{LaO}_{9}$ skeleton modes of the nonahydrate $\left[\mathrm{La}\left(\mathrm{OH}_{2}\right)_{9}\right]^{3+}$. The irreducible representation of the vibrational modes is as follows: $\Gamma_{\text {vib }}\left(D_{3 \mathrm{~h}}\right)=3 \mathrm{a}^{\prime}{ }_{1}(\mathrm{Ra})+\mathrm{a}^{\prime}{ }_{2}+5 \mathrm{e}^{\prime}(\mathrm{Ra}$, i.r. $)+\mathrm{a}^{\prime \prime}{ }_{1}+3 \mathrm{a}^{\prime \prime}{ }_{2}$ (i.r. $)+$ $3 \mathrm{e}^{\prime \prime}(\mathrm{Ra})$. Two stretching modes and a bending mode are expected with character $\mathrm{a}_{1}^{\prime}$ and these modes are Raman active only. Two stretching modes and three bending modes occur with character $\mathrm{e}^{\prime}$ and these modes are infrared and Raman active. A stretching mode and two bending modes for character $\mathrm{a}^{\prime \prime}{ }_{2}$ are expected and these n.m.'s are infrared active only while three modes (one stretch and two bending modes) with character $\mathrm{e}^{\prime \prime}$ are only Raman active. The modes with character $\mathrm{a}_{2}^{\prime}$ and $\mathrm{a}^{\prime \prime}{ }_{1}$ are torsional modes and are not active. However, it was evident that only the symmetric La-O stretching mode appears in the Raman effect. The remaining $\mathrm{LaO}_{9}$ modes are too weak to be identified in Raman and this has also been observed for other metal ion-oxygen modes in aqueous solution. ${ }^{4}$ The $\mathrm{La}\left(\mathrm{ClO}_{4}\right)_{3}$ solution spectra reveals a Raman mode for the $\left[\mathrm{La}\left(\mathrm{OH}_{2}\right)_{9}{ }^{3+}\right]$ species, which is very weak, strongly polarized and broad at $343 \mathrm{~cm}^{-1}$. A $0.249 \mathrm{~mol} \mathrm{~L}^{-1} \mathrm{La}\left(\mathrm{ClO}_{4}\right)_{3}$ solution is presented in Fig. 1. In neither $\mathrm{NaClO}_{4}(\mathrm{aq})$ nor $\mathrm{HClO}_{4}(\mathrm{aq})$ was this mode observed and must therefore stem from a symmetrical vibration connected to a La-O stretching band.

The perchlorate modes are well characterized so only a brief description is given. ${ }^{4}$ The $\mathrm{ClO}_{4}{ }^{-}$ion possesses $T_{\mathrm{d}}$ symmetry and has nine modes of internal vibrations spanning the representation $\Gamma_{\text {vib }}\left(T_{\mathrm{d}}\right)=\mathrm{a}_{1}(\mathrm{Ra})+\mathrm{e}(\mathrm{Ra})+2 \mathrm{f}_{2}(\mathrm{Ra}$, i.r. $)$. All n.m. are Raman active, but in i.r. only the $f_{2}$ modes are active. The spectra of $\mathrm{La}\left(\mathrm{ClO}_{4}\right)_{3}(\mathrm{aq})$ show the predicted four Raman-active bands for the tetrahedral $\mathrm{ClO}_{4}{ }^{-}(\mathrm{aq})$. The $\nu_{1}\left(\mathrm{a}_{1}\right) \mathrm{ClO}_{4}{ }^{-}$band centred at $931.5 \mathrm{~cm}^{-1}$ is totally polarized $(\rho=0.005)$ whereas $\nu_{3}\left(\mathrm{f}_{2}\right) \mathrm{ClO}_{4}{ }^{-}$ centred at $1105 \mathrm{~cm}^{-1}$ is depolarized as are the deformation modes $\nu_{4}\left(\mathrm{f}_{2}\right) \mathrm{ClO}_{4}{ }^{-}$at $631 \mathrm{~cm}^{-1}$ and $\nu_{2}(\mathrm{e}) \mathrm{ClO}_{4}{ }^{-}$at $463 \mathrm{~cm}^{-1}$ (Fig. 1).

In addition to the isotropic mode, $\nu_{1} \mathrm{LaO}_{9}$ at $343 \mathrm{~cm}^{-1}$ (fwhh $=49 \pm 2 \mathrm{~cm}^{-1}$ ) a very weak, broad mode centered at $170 \pm 10$ $\mathrm{cm}^{-1}$ can be observed in aqueous $\mathrm{La}\left(\mathrm{ClO}_{4}\right)_{3}$ solution (isotropic Raman scattering). The mode can also be seen in pure water at $\sim 175 \mathrm{~cm}^{-1}$ and is moderately intense but slightly polarized. This mode has been assigned to a restricted translational mode of the $\mathrm{H}$-bonded water molecules and is strongly anion and 


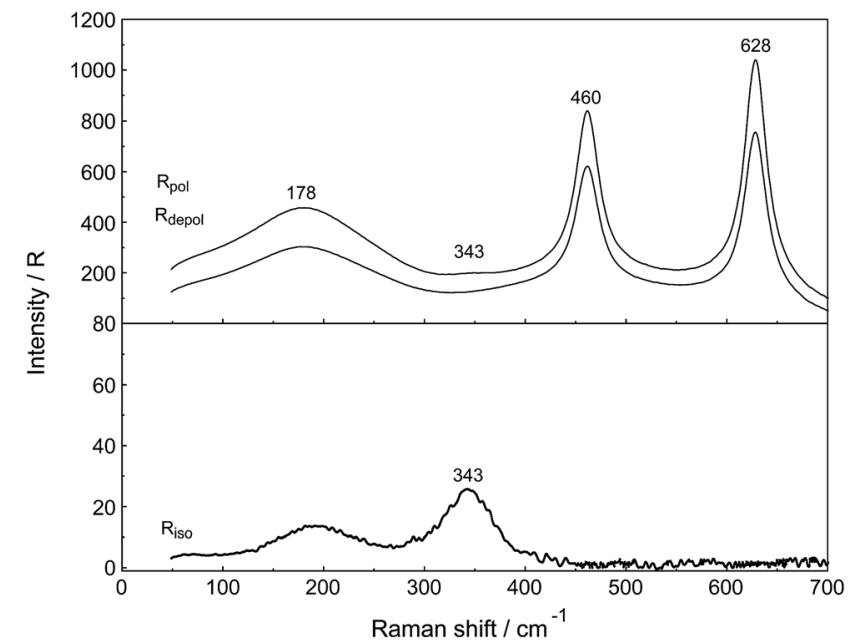

Fig. 1 Raman scattering profiles of a $0.249 \mathrm{~mol} \mathrm{~L}^{-1}\left(R_{\mathrm{w}}=214\right)$ $\mathrm{La}\left(\mathrm{ClO}_{4}\right)_{3}(\mathrm{aq})$. Upper panel: $R_{\text {pol }}$ and $R_{\text {depol }}$ scattering. Note the very weak band at $343 \mathrm{~cm}^{-1}$ due to the symmetric breathing mode of $\left[\mathrm{La}\left(\mathrm{OH}_{2}\right)_{9}\right]^{3+}$. In addition, the deformation modes of $\mathrm{ClO}_{4}{ }^{-}$(aq) which dominate the spectrum at $460 \mathrm{~cm}^{-1}$ and $628 \mathrm{~cm}^{-1}$ are shown. The band at $178 \mathrm{~cm}^{-1}\left(R_{\mathrm{Vv}}\right)$ is due to the restricted $\mathrm{O}-\mathrm{H} \cdots \mathrm{O}$ bonds of the water $\mathrm{H}$-bond network. Lower panel: Isotropic scattering in $R$-format. Note the very weak band at $343 \mathrm{~cm}^{-1}$ due to the symmetric breathing $\mathrm{L}-\mathrm{O}$ mode. The isotropic mode at $182 \mathrm{~cm}^{-1}$ is due to the restricted $\mathrm{O}-\mathrm{H} \cdots \mathrm{O}$ bonds of the water $\mathrm{H}$-bond network.

concentration dependent. ${ }^{4,22} \mathrm{~A} \mathrm{La}\left(\mathrm{ClO}_{4}\right)_{3}$ solution in heavy water shows, in addition to the perchlorate modes, a strongly polarized band at $326 \mathrm{~cm}^{-1}$ which is due to the $\nu_{1} \mathrm{LaO}_{9}$ at $326 \mathrm{~cm}^{-1}$ (fwhh $=47 \pm 2 \mathrm{~cm}^{-1}$ ) of the deuterated analog of the nonahydrate, $\left[\mathrm{La}\left(\mathrm{OD}_{2}\right)_{9}\right]^{3+}\left(\mathrm{D}_{2} \mathrm{O}\right)$.

Relative intensity measurements confirm that the scattering intensity of $\nu_{1}$ La-O mode is very weak and this may be the reason why the mode has been observed as an obscured shoulder in aqueous $\mathrm{La}^{3+}$ salt solutions in previous publications. ${ }^{23}$ The scattering coefficient, $S_{\mathrm{h}}$ for the $\nu_{1}$ La-O mode at 0.030 is small.

\subsection{The unassociated $\mathrm{SO}_{4}{ }^{2-}$ (aq)}

Unassociated $\mathrm{SO}_{4}{ }^{2-}(\mathrm{aq})$, in $\left(\mathrm{NH}_{4}\right)_{2} \mathrm{SO}_{4}(\mathrm{aq})$ for instance, has been described in detail. ${ }^{24}$ Although in $\mathrm{Na}_{2} \mathrm{SO}_{4}$ solutions at higher concentrations, ion pairs such as outer-outer sphere and outer-sphere ion-pairs are formed, in dilute solutions $<0.1 \mathrm{~mol}$ $\mathrm{L}^{-1}$ the equilibrium concentrations are small relative to "free" sulfate. In a $0.101 \mathrm{~mol} \mathrm{~L}^{-1} \mathrm{Na}_{2} \mathrm{SO}_{4}$ solution $\sim 13 \%$ of the total sulfate exists as ion pairs, mainly as outer-outer-sphere ion pairs while $87 \%$ are considered "free" or unassociated, $\mathrm{SO}_{4}{ }^{2-}(\mathrm{aq}) .{ }^{25}$ With further dilution, the fraction of ion pairs diminishes significantly and reaches zero at infinite dilution. Therefore, dilute $\mathrm{Na}_{2} \mathrm{SO}_{4}$ solutions shall be briefly discussed and compared with $\mathrm{La}_{2}\left(\mathrm{SO}_{4}\right)_{3}$ solutions. An overview Raman spectrum of a $0.101 \mathrm{~mol} \mathrm{~L}^{-1} \mathrm{Na}_{2} \mathrm{SO}_{4}(\mathrm{aq})$ from $100-1900 \mathrm{~cm}^{-1}$ is presented in Fig. 2. The spectral characteristics of the nonassociated $\mathrm{SO}_{4}{ }^{2-}(\mathrm{aq})$ ion have been conducted. ${ }^{26}$ Here, however, a brief discussion of the results relevant to the ligated sulfate is presented.

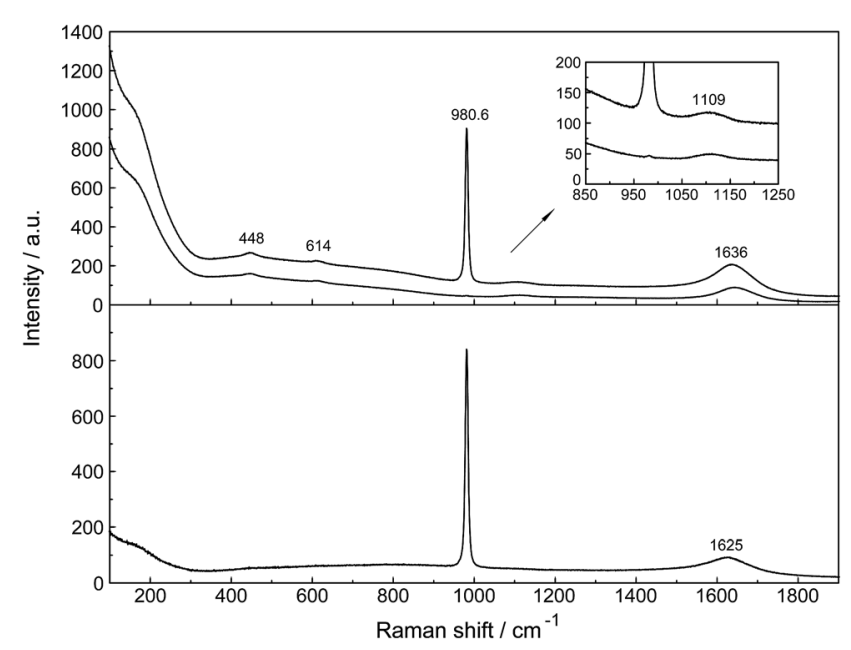

Fig. 2 Overview Raman profiles of a $0.101 \mathrm{~mol} \mathrm{~L}^{-1} \mathrm{Na}_{2} \mathrm{SO}_{4}$ solution. The $I_{\mathrm{VV}}$ and $I_{\mathrm{VH}}$ scattering orientations (upper panel) are given and in the lower panel the isotropic scattering.

The non-associated $\mathrm{SO}_{4}{ }^{2-}(\mathrm{aq})$ ion possesses $T_{\mathrm{d}}$ symmetry and thus nine modes of internal vibration, having the representation: $\Gamma_{\text {vib }}\left(T_{\mathrm{d}}\right)=\mathrm{a}_{1}(\mathrm{R})+\mathrm{e}(\mathrm{R})+2 \mathrm{f}_{2}(\mathrm{R}, \mathrm{IR})$. All vibrational modes are Raman active, one mode with character $\mathrm{a}_{1}$ is totally polarized, and three modes with character e and $\mathrm{f}_{2}$ are depolarized but only the $\mathrm{f}_{2}$ modes are IR allowed.

In the IR spectrum only two sulfate bands are active, namely $\nu_{4}\left(\mathrm{f}_{2}\right)$ and $\nu_{3}\left(\mathrm{f}_{2}\right)$ located at $618 \mathrm{~cm}^{-1}$ and $1104 \mathrm{~cm}^{-1}$ respectively ${ }^{24}$ but all four modes are Raman active. Detailed Raman spectroscopic characterizations of the $\mathrm{SO}_{4}{ }^{2-}(\mathrm{aq})$ bands are given in ref. 24 . The $\nu_{1}\left(\mathrm{a}_{1}\right)-\mathrm{SO}_{4}{ }^{2-}$ mode is the strongest band in the sulfate spectrum. The band for a $0.101 \mathrm{~mol} \mathrm{~L}^{-1} \mathrm{Na}_{2} \mathrm{SO}_{4}(\mathrm{aq})$ centred on $980.69 \mathrm{~cm}^{-1}$ (fwhh $=6.05 \pm 0.05 \mathrm{~cm}^{-1}$ ) is almost totally polarized $(\rho=0.0035)$ whereas the $\nu_{3}\left(\mathrm{f}_{2}\right)-\mathrm{SO}_{4}{ }^{2-}$ band centred on $1109 \mathrm{~cm}^{-1}\left(\mathrm{fwhh}=65.0 \mathrm{~cm}^{-1}\right)$ is depolarized. The deformation modes $\nu_{4}\left(\mathrm{f}_{2}\right)-\mathrm{SO}_{4}{ }^{2-}$ at $614 \mathrm{~cm}^{-1}$ (fwhh $=31 \mathrm{~cm}^{-1}$ ) and $\nu_{2}(\mathrm{e})-$ $\mathrm{SO}_{4}{ }^{2-}$ at $448 \mathrm{~cm}^{-1}$ (fwhh $=35 \mathrm{~cm}^{-1}$ ) are depolarized as well.

At low frequencies, a broad and weak mode at $180 \mathrm{~cm}^{-1}$ (fwhh $=168 \mathrm{~cm}^{-1}$ ) was observed in the isotropic $R$-spectrum. ${ }^{24}$ This mode is also observable in pure water at $175 \mathrm{~cm}^{-1}$ and has been attributed to $\mathrm{H}$-bonded water molecules. ${ }^{26,27}$ In $\mathrm{Na}_{2} \mathrm{SO}_{4}$ (aq) it may be assigned to the restricted translational modes of both $\mathrm{OH} \cdots \mathrm{O}$ and $\mathrm{OH} \cdots\left(\mathrm{OSO}_{3}\right)^{2-}$ hydrogen-bonds thereby the contribution of the $\mathrm{OH} \cdots\left(\mathrm{OSO}_{3}\right)^{2-}$ hydrogen-bonds increases with increasing $\mathrm{Na}_{2} \mathrm{SO}_{4}$ concentration. In a concentrated, saturated $\mathrm{Na}_{2} \mathrm{SO}_{4}$ solution, $1.617 \mathrm{~mol} \mathrm{~L}{ }^{-1}$, the restricted translational mode, $\nu \mathrm{OH} \cdots \mathrm{O}$ was observed at $185 \mathrm{~cm}^{-1}$ with a fwhh at $130 \mathrm{~cm}^{-1}$ while in dilute solutions the restricted translational mode is determined by the $\mathrm{OH} \cdots \mathrm{O}$ hydrogen bonds in water and only slightly influenced by $\mathrm{OH} \cdots\left(\mathrm{OSO}_{3}\right)^{2-}$ hydrogen-bonds. The corresponding bending mode of this unit appears at $\sim 60 \mathrm{~cm}^{-1} .^{26,27}$

The $\nu_{1}-\mathrm{SO}_{4}{ }^{2-}$ band shape in dilute $\mathrm{Na}_{2} \mathrm{SO}_{4}(\mathrm{aq})$ is symmetrical in both Raman polarization arrangements but other band parameters vary slightly with concentration (Fig. 3, panel A and $\mathrm{B}$, data with open squares). For example, at $23{ }^{\circ} \mathrm{C}$ for a 1.617 

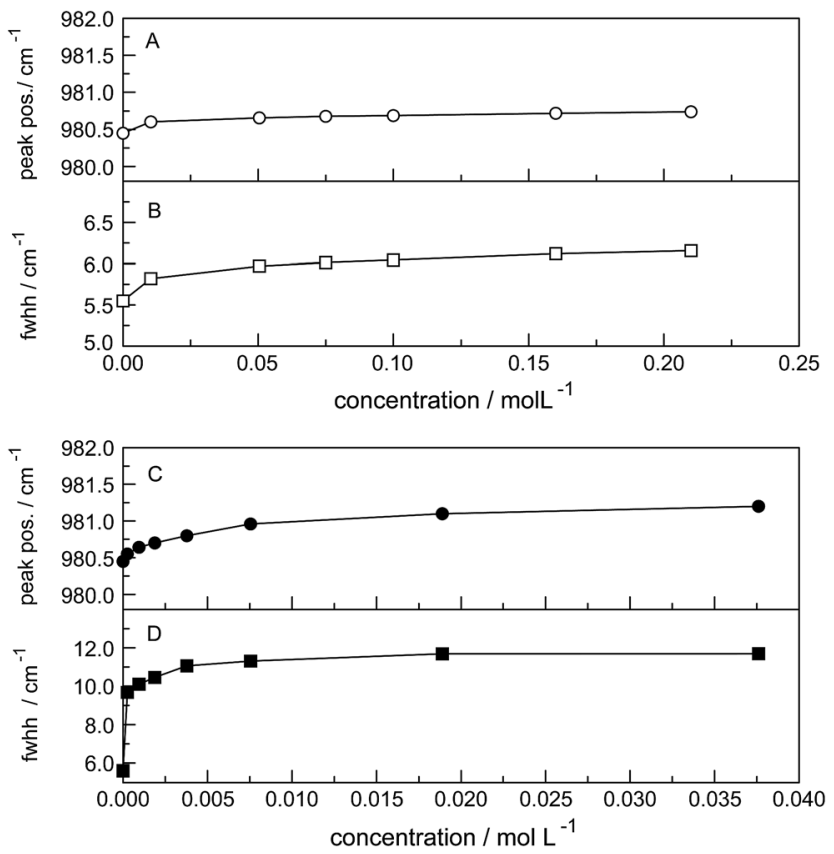

Fig. 3 Concentration effects at $23{ }^{\circ} \mathrm{C}$ on the $\nu_{1}-\mathrm{SO}_{4}{ }^{2-}$ mode at $\mathrm{ca}$. $980 \mathrm{~cm}^{-1}$ in $\mathrm{Na}_{2} \mathrm{SO}_{4}$ solutions (open circles) and in $\mathrm{La}_{2}\left(\mathrm{SO}_{4}\right)_{3}$ solutions (after subtraction of the $991 \mathrm{~cm}^{-1}$ component, filled circles); (A and C): peak position $\left(\nu_{\max }\right)$; $(B$ and $\mathrm{D})$ : fwhh.

mol L ${ }^{-1} \mathrm{Na}_{2} \mathrm{SO}_{4}$ solution $\left(R_{\mathrm{w}}=32.75\right), \nu_{\max }$ for this isotropic band appears at $981.04 \mathrm{~cm}^{-1}$ with a fwhh $=6.60 \mathrm{~cm}^{-1}$, for a $0.101 \mathrm{~mol} \mathrm{~L}^{-1}$ solution $\left(R_{\mathrm{w}}=552.2\right) \nu_{\max }$ appears at 980.69 $\mathrm{cm}^{-1}$ with a fwhh $=6.05 \mathrm{~cm}^{-1}$. For an infinitely dilute solution (extrapolation to zero concentration) the $\nu_{1}-\mathrm{SO}_{4}{ }^{2-}$ band appears at $980.45 \mathrm{~cm}^{-1}$ and a fwhh $=(5.55 \pm 0.05) \mathrm{cm}^{-1}$. For present purposes, it is relevant that the symmetric profile of the $\nu_{1}$ $\mathrm{SO}_{4}{ }^{2-}$ mode was independent of the salt concentration over the entire range studied $\left(\leq 1.617 \mathrm{~mol} \mathrm{~L}^{-1}\right)$. The $\nu_{1}-\mathrm{SO}_{4}{ }^{2-}$ band is the strongest band in the $\mathrm{SO}_{4}{ }^{2-}(\mathrm{aq})$ - Raman spectrum and the intensity ratio of $\nu_{1}-\mathrm{SO}_{4}{ }^{2-}$ band area to $\nu_{3}-\mathrm{SO}_{4}{ }^{2-}$ band area is $9: 1$.

The band contour of the antisymmetric S-O stretching mode, $\nu_{3}-\mathrm{SO}_{4}{ }^{2-}$ is also symmetrical in both polarization arrangements but band parameters vary slightly with concentration. For example, at $23{ }^{\circ} \mathrm{C}$ for a $1.617 \mathrm{~mol} \mathrm{~L}^{-1} \mathrm{Na}_{2} \mathrm{SO}_{4}$ solution, $\nu_{\max }$ is found at $(1112 \pm 2) \mathrm{cm}^{-1}$ and shifted to slightly lower wavenumbers as the concentration was decreased, reaching $(1106 \pm 2) \mathrm{cm}^{-1}$ at infinite dilution. The fwhh decreased from $(76 \pm 2) \mathrm{cm}^{-1}$ for a $1.617 \mathrm{~mol} \mathrm{~L}^{-1}$ salt solution to $(67 \pm 2) \mathrm{cm}^{-1}$ for a $0.100 \mathrm{~mol} \mathrm{~L}^{-1}$ solution reaching $(64 \pm 2)$ $\mathrm{cm}^{-1}$ at infinite dilution. It is important to state that the symmetric profile of the $\nu_{3}-\mathrm{SO}_{4}{ }^{2-}$ band which is completely depolarized is independent of the $\mathrm{Na}_{2} \mathrm{SO}_{4}$ concentration over the entire range studied (Fig. 2).

\subsection{Raman spectra of $\mathrm{La}_{2}\left(\mathrm{SO}_{4}\right)_{3}(\mathrm{aq})$}

The Raman spectra of $\mathrm{La}_{2}\left(\mathrm{SO}_{4}\right)_{3}$ in aqueous solution show additional features to those in the unassociated sulfate spectra and the $\left[\mathrm{La}\left(\mathrm{OH}_{2}\right)_{9}\right]^{3+}(\mathrm{aq})$ mode which have been described above. $\mathrm{La}_{2}\left(\mathrm{SO}_{4}\right)_{3}$ is only sparingly soluble in water and the Raman signals are therefore of low intensity and the spectra are dominated by the solvent, water. Nevertheless these additional spectroscopic features could be observed and are now discussed in detail.

An overview Raman spectrum of the $0.0376 \mathrm{~mol} \mathrm{~L}^{-1}$ $\mathrm{La}_{2}\left(\mathrm{SO}_{4}\right)_{3}$ solution is presented in Fig. 4. Because of the low solute concentration, the sulfate bands appear weak and the scattering spectrum is dominated by the bands of the solute, water. The $\nu_{1}\left(\mathrm{a}_{1}\right) \mathrm{SO}_{4}{ }^{2-}$ stretching profile shows two band components at $981 \mathrm{~cm}^{-1}$ and at $991 \mathrm{~cm}^{-1}$. The weak antisymmetric stretching mode, $\nu_{3} \mathrm{SO}_{4}{ }^{2-}$ at $1112 \mathrm{~cm}^{-1}$ appears broader compared to a comparable $\mathrm{Na}_{2} \mathrm{SO}_{4}$ solution. Furthermore, in the terahertz frequency range, the La-O breathing mode, normally at $343 \mathrm{~cm}^{-1}$, appears in the difference spectrum of the $0.0376 \mathrm{~mol} \mathrm{~L}^{-1} \mathrm{La}_{2}\left(\mathrm{SO}_{4}\right)_{3}$ solution as a broad feature at $\sim 328 \mathrm{~cm}^{-1}$ with two separate component bands, one at 343 $\mathrm{cm}^{-1}$ assigned to the La-O breathing mode of $\left[\mathrm{La}\left(\mathrm{OH}_{2}\right)_{9}\right]^{3+}(\mathrm{aq})$ and one at $312 \mathrm{~cm}^{-1}$ assigned to hydrated $\mathrm{La}^{3+}$ where sulfate occurs in the first hydration shell, $\left[\mathrm{La}\left(\mathrm{OH}_{2}\right)_{8} \mathrm{OSO}_{3}\right]^{+}(\mathrm{aq})$ (Fig. 5). With further dilution of $\mathrm{La}_{2}\left(\mathrm{SO}_{4}\right)_{3}$ the very small scattering coefficient of this La-O breathing mode prevents further observation of this band.

The split of the $\nu_{1}\left(\mathrm{a}_{1}\right) \mathrm{SO}_{4}{ }^{2-}$ stretching band into a band at $981 \mathrm{~cm}^{-1}$ and a pronounced shoulder at $991 \mathrm{~cm}^{-1}$ becomes immediately obvious in Fig. 6B. In $\mathrm{Na}_{2} \mathrm{SO}_{4}(\mathrm{aq})$ the strongly polarized mode at $991 \mathrm{~cm}^{-1}$ is absent while in a variety of divalent and trivalent metal sulfate solutions sulfato-complex species could be observed. ${ }^{\mathbf{8 1 1 , 1 2 , 2 4}}$ In Fig. 7, a concentration plot of $\nu_{1}\left(\mathrm{a}_{1}\right) \mathrm{SO}_{4}{ }^{2-}$ band profiles are given, showing the concentration dependence of four representative Raman

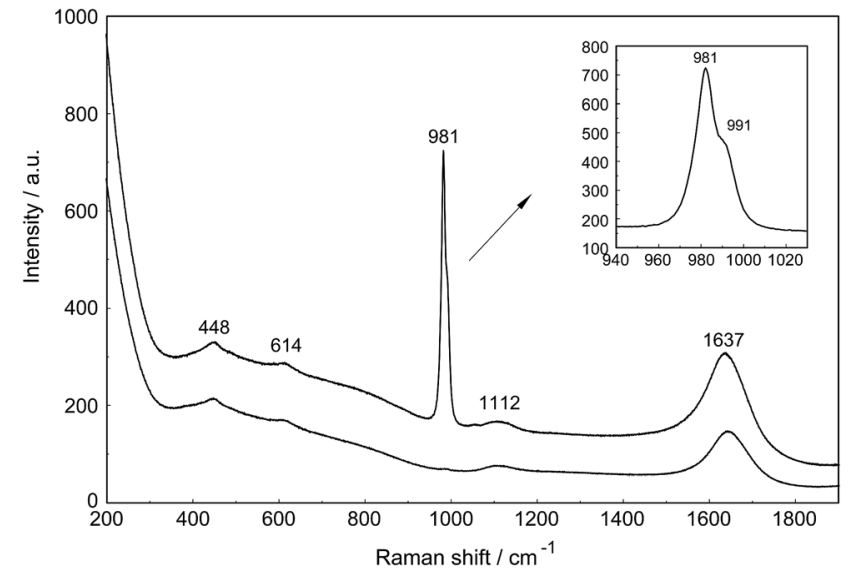

Fig. 4 Raman scattering profiles (polarized and depolarized) of a $0.0376 \mathrm{~mol} \mathrm{~L}^{-1} \mathrm{La}_{2}\left(\mathrm{SO}_{4}\right)_{3}$ solution in the low wavenumber region from $200-1900 \mathrm{~cm}^{-1}$. In addition to the sulfate modes at 448,614 , 981 and $1112 \mathrm{~cm}^{-1}$ the spectrum is dominated by the solvent with its two very broad librational bands at $\sim 455$ and $\sim 720 \mathrm{~cm}^{-1}$ of water and the deformation mode at $1637 \mathrm{~cm}^{-1}\left(I_{\text {pol }}\right.$ scattering). Note that the $\nu_{1}$ $\mathrm{SO}_{4}{ }^{2-}$ stretching band, the strongest sulfate band is split into two component bands at 982 and $991 \mathrm{~cm}^{-1}$. Both $\mathrm{SO}_{4}{ }^{2-}$ deformation modes at 451 and $614 \mathrm{~cm}^{-1}$ appear on the broad librational band profile as weak bands. The $\nu_{3} \mathrm{SO}_{4}{ }^{2-}$ antisymmetric stretching band at $1112 \mathrm{~cm}^{-1}$ is also of weak intensity. 


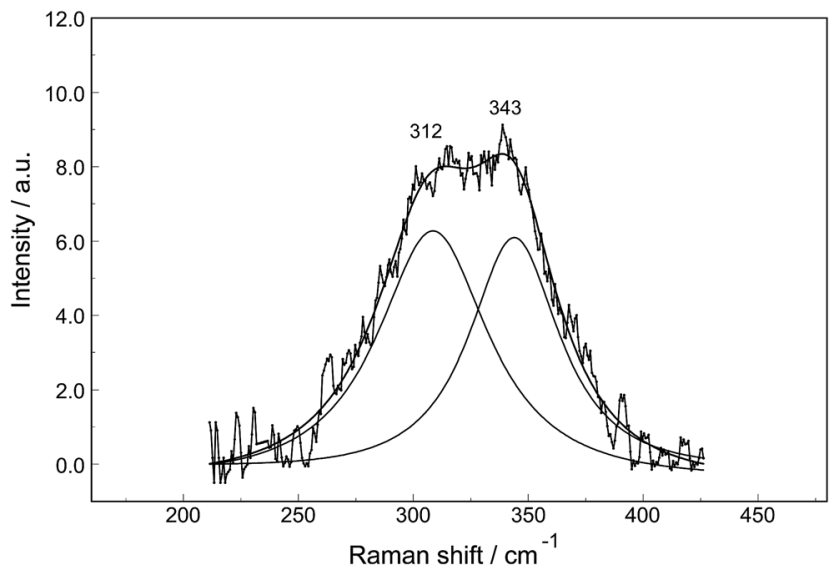

Fig. 5 Band fit result on a difference Raman scattering profile (polarized scattering) of a $0.0376 \mathrm{~mol} \mathrm{~L}^{-1} \mathrm{La}_{2}\left(\mathrm{SO}_{4}\right)_{3}$ solution from which the water background was subtracted. In addition to the difference Raman spectrum of the broad band feature, the sum curve of the fit and the two band components at $312 \mathrm{~cm}^{-1}$ and $343 \mathrm{~cm}^{-1}$ are shown.

spectra from 0.0303-0.000263 $\mathrm{mol} \mathrm{L}^{-1}$. With dilution, the equilibrium concentration of the band at $991 \mathrm{~cm}^{-1}$ diminishes while the one of the "free" sulfate rises. The band parameters for the $980 \mathrm{~cm}^{-1}$ band and the band at $991 \mathrm{~cm}^{-1}$ is given in Table S1.† It is interesting to note that both sulfate stretching modes are strongly polarized and in the anisotropic scattering both component bands appear at 981 and $991 \mathrm{~cm}^{-1}$ (Fig. 6B) and the polarization degrees are 0.004 and 0.006 respectively. This spectroscopic observation contradicts the observation made in a similar system, $\mathrm{MgSO}_{4}(\mathrm{aq})$, for which a dynamic exchange model was proposed to explain the occurrence of the band at $995 \mathrm{~cm}^{-1}$. (The $995 \mathrm{~cm}^{-1}$ band in $\mathrm{MgSO}_{4}(\mathrm{aq})$, however, is the band of a sulfato-complex species. ${ }^{24,28}$ ) The deformation bands of sulfate, $\nu_{2} \mathrm{SO}_{4}{ }^{2-}$ at $448 \mathrm{~cm}^{-1}$ and the band $\nu_{4}$ at $614 \mathrm{~cm}^{-1}$ are broadened compared to the ones in $\mathrm{Na}_{2} \mathrm{SO}_{4}(\mathrm{aq})$ of comparable sulfate concentrations (Fig. 2, 3 and 6A). These two deformation bands are depolarized in the Raman scattering as shown in Fig. 2 and 6A. The anti-symmetric stretch $\nu_{3} \mathrm{SO}_{4}{ }^{2-}$ is much broader than $\mathrm{Na}_{2} \mathrm{SO}_{4}(\mathrm{aq})$ of comparable sulfate concentration and shows a band contour with peak positions at $1088 \mathrm{~cm}^{-1}, 1127 \mathrm{~cm}^{-1}$ and $1158 \mathrm{~cm}^{-1}$ and in the broad band at $1109 \mathrm{~cm}^{-1}$ for "free" sulfate (compare band contour of $\mathrm{Na}_{2}$ $\mathrm{SO}_{4}(\mathrm{aq})$ spectra). The measured anisotropic band profile of $\nu_{3}$ $\mathrm{SO}_{4}{ }^{2-}$ is shown in Fig. $\mathrm{S} 1 \uparrow$ together with the sum curve of the band fit. All these spectroscopic features of the sulfate in $\mathrm{La}_{2}\left(\mathrm{SO}_{4}\right)_{3}$ solutions lead to the conclusion that sulfate must have penetrated the first hydration shell of $\mathrm{La}^{3+}(\mathrm{aq})$ forming a well-defined $\mathrm{La}^{3+}$-sulfato complex. In the terahertz frequency range of $\mathrm{La}_{2}\left(\mathrm{SO}_{4}\right)_{3}(\mathrm{aq})$ of a $0.376 \mathrm{~mol} \mathrm{~L}^{-1}$ solution, as mentioned above, the $\mathrm{La}-\mathrm{O}$ band, of the $\mathrm{LaO}_{9}$ skeleton appears as a broad feature at $\sim 328 \mathrm{~cm}^{-1}$ while the fully hydrated, $\left[\mathrm{La}\left(\mathrm{OH}_{2}\right)_{9}\right]^{3+}$ occurs at $343 \mathrm{~cm}^{-1}$. The downshift of the $\mathrm{La}^{3+}$-sulfato complex, $\left[\mathrm{La}\left(\mathrm{OH}_{2}\right)_{8} \mathrm{OSO}_{3}\right]^{+}$compared with the fully hydrated cation was detected in other trivalent-metal sulfate solutions. It should be pointed out that the scattering intensity of the broad $\mathrm{La}-\mathrm{O}$
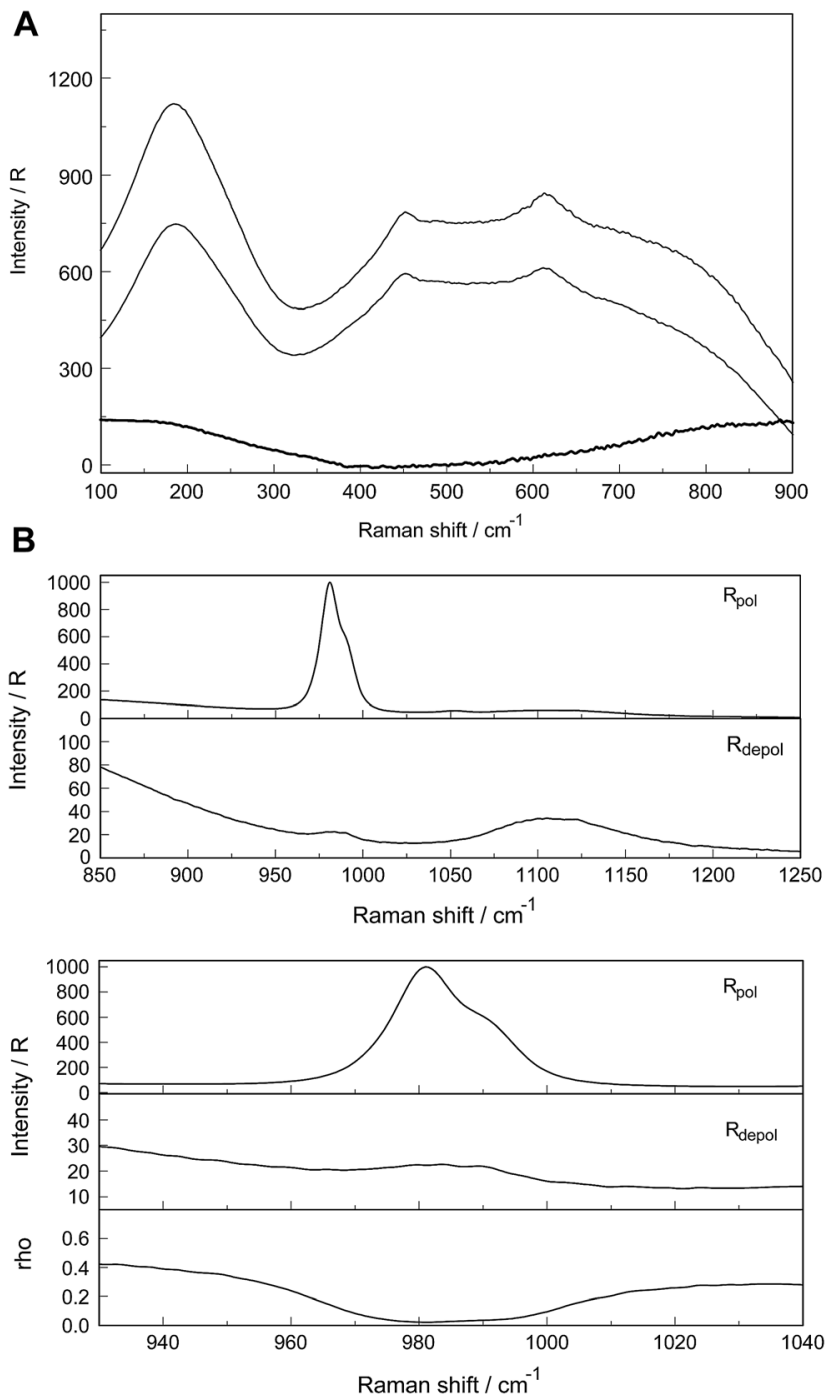

Fig. 6 (A) Raman scattering profiles (polarized, depolarized and isotropic) of a $0.0376 \mathrm{~mol} \mathrm{~L}^{-1} \mathrm{La}_{2}\left(\mathrm{SO}_{4}\right)_{3}$ solution in the low wavenumber region from $100-900 \mathrm{~cm}^{-1}$. Shown are the restricted translation band $\mathrm{O}-\mathrm{H} \cdots \mathrm{O}$ at $181 \mathrm{~cm}^{-1}$ and the very broad and dominating bands at $\mathrm{ca} .455$ and $720 \mathrm{~cm}^{-1}$ due to the librational bands of $\mathrm{H}_{2} \mathrm{O}$. The two weak deformation modes of $\mathrm{SO}_{4}{ }^{2-}$ at 448 and $614 \mathrm{~cm}^{-1}$ are "sitting" on the broad librational band structure. (B) Raman scattering profiles of a $0.0376 \mathrm{~mol} \mathrm{~L}^{-1} \mathrm{La}_{2}\left(\mathrm{SO}_{4}\right)_{3}$ solution. Upper panel: Wavenumber rage from $850-1250 \mathrm{~cm}^{-1}$ showing the $\nu_{1} \mathrm{SO}_{4}{ }^{2-}$ and $\nu_{3} \mathrm{SO}_{4}{ }^{2-}$ stretching region of sulfate. Lower panel: Enlarged wavenumber region from $920-1040 \mathrm{~cm}^{-1}$ depicting the $\mathrm{S}-\mathrm{O}$ stretching band region. Note the split of the $\mathrm{S}-\mathrm{O}$ stretching band into a band at 981.5 $\mathrm{cm}^{-1}$ of "free" $\mathrm{SO}_{4}{ }^{2-}$ and coordinated $\mathrm{SO}_{4}{ }^{2-}$ at $991.5 \mathrm{~cm}^{-1}$ appearing as a well pronounced shoulder. Underneath is the depolarization degree as a function of wavenumbers.

features is very small and the solutions are quite dilute. Only in $\mathrm{Al}_{2}\left(\mathrm{SO}_{4}\right)_{3}, \mathrm{Ga}_{2}\left(\mathrm{SO}_{4}\right)_{3}$, and $\mathrm{In}_{2}\left(\mathrm{SO}_{4}\right)_{3}$ solutions which are considerably more soluble than $\mathrm{La}_{2}\left(\mathrm{SO}_{4}\right)_{3}$ and therefore much easier to detect, is such a split into the aqua mode of the fully hydrated species observable without the sulfate and partially hydrated metal-sulfato complex species. ${ }^{\mathbf{8 , 1 1 , 1 2}}$

An overview Raman spectrum of a $0.035 \mathrm{~mol} \mathrm{~L}^{-1} \mathrm{La}_{2}\left(\mathrm{SO}_{4}\right)_{3}$ solution in heavy water is presented in Fig. S2 (ESI†). The 


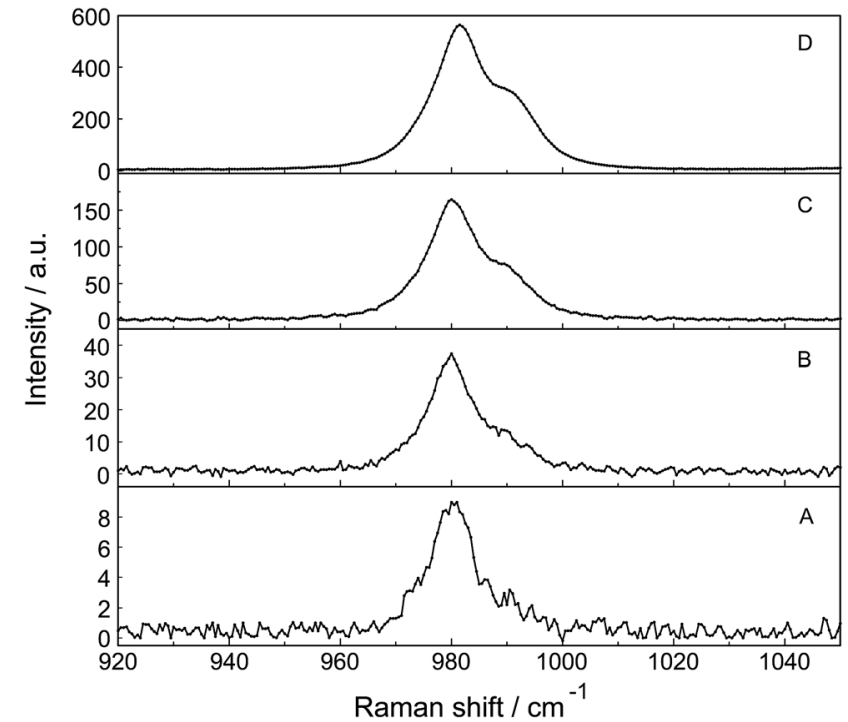

Fig. 7 Dilution series of polarized Raman scattering profiles of selected $\mathrm{La}_{2}\left(\mathrm{SO}_{4}\right)_{3}$ solutions in the wavenumber range from 920$1060 \mathrm{~cm}^{-1}\left(\nu_{1} \mathrm{SO}_{4}{ }^{2-}\right.$ stretching region). From bottom to top: (A) $0.000263 \mathrm{~mol} \mathrm{~L}^{-1}$, (B) $0.00121 \mathrm{~mol} \mathrm{~L}^{-1}$, (C) $0.00606 \mathrm{~mol} \mathrm{~L}^{-1}$ and (D) $0.0302 \mathrm{~mol} \mathrm{~L}^{-1} \mathrm{La}_{2}\left(\mathrm{SO}_{4}\right)_{3}$ solution. Note the split of the $\mathrm{S}-\mathrm{O}$ stretching band into a band at $981.3 \mathrm{~cm}^{-1}$ of "free" $\mathrm{SO}_{4}{ }^{2-}$ and coordinated $\mathrm{SO}_{4}{ }^{2-}$ at $991 \mathrm{~cm}^{-1}$ as a separate band component.

spectrum is dominated by the solvent $\mathrm{D}_{2} \mathrm{O}(\mathrm{l})$ and the deformation mode at $1204 \mathrm{~cm}^{-1}$, a broad combination band at 1554 $\mathrm{cm}^{-1}\left(\nu_{2}+\nu_{\mathrm{L}}\right)$ and the O-D stretching profile with a band doublet at 2382 and $2477 \mathrm{~cm}^{-1}$ as well as a shoulder at 2680 $\mathrm{cm}^{-1}$. A detailed spectrum is given in Fig. $\mathrm{S} 3 \dagger$ showing the $\nu_{1}\left(\mathrm{a}_{1}\right)$ $\mathrm{SO}_{4}{ }^{2-}$ band complex with two band components at $981 \mathrm{~cm}^{-1}$ and $991.4 \mathrm{~cm}^{-1}$. This $\nu_{1}\left(\mathrm{a}_{1}\right) \mathrm{SO}_{4}{ }^{2-}$ band complex observed in $\mathrm{La}_{2}\left(\mathrm{SO}_{4}\right)_{3}\left(\mathrm{D}_{2} \mathrm{O}\right)$ compares with the spectra found in solutions of light water (compare Fig. 4). This finding reinforces the assignment of sulfate band components as bands of "free" sulfate and "bound" sulfate at $981 \mathrm{~cm}^{-1}$ and $991 \mathrm{~cm}^{-1}$ respectively.

\subsection{Quantitative analysis of sulfato-complex formation in $\mathrm{La}_{2}\left(\mathrm{SO}_{4}\right)_{3}(\mathrm{aq})$}

The $\log \beta_{1}$ value for the hydrolysis of $\left[\mathrm{La}\left(\mathrm{OH}_{2}\right)_{9}\right]^{3+}$ according to: $\left[\mathrm{La}\left(\mathrm{H}_{2} \mathrm{O}\right)_{9}\right]^{3+}+\mathrm{H}_{2} \mathrm{O} \leftrightarrow\left[\mathrm{La}\left(\mathrm{H}_{2} \mathrm{O}\right)_{8} \mathrm{OH}\right]^{2+}+\mathrm{H}_{3} \mathrm{O}^{+}$is at -8.5 for 25 ${ }^{\circ} \mathrm{C}^{29,30}$ Therefore, $\mathrm{La}^{3+}(\mathrm{aq})$, in contrast to $\mathrm{Fe}^{3+}(\mathrm{aq})$ which acts as a strong acid in solution $\left(\log \beta_{1}=-2.19\right.$ (ref. 31)) is not markedly hydrolyzed. A $0.01 \mathrm{~mol} \mathrm{~L}{ }^{-1} \mathrm{La}_{2}\left(\mathrm{SO}_{4}\right)_{3}$ solution shows a $\mathrm{pH}$ value of 5.53 and therefore the formation of hydrogen sulfate, $\mathrm{HSO}_{4}{ }^{-}$may be neglected.

The association between $\mathrm{La}^{3+}(\mathrm{aq})$ and $\mathrm{SO}_{4}{ }^{2-}(\mathrm{aq})$ ions is generally thought to occur via a three step process, referred to as the Eigen mechanism, ${ }^{32,33}$ in which the strongly hydrated ions combine initially to form an outer-outer-sphere complex. The two interposing water molecules are then lost successively, forming outer-sphere and ultimately inner-sphere complexes. This process is summarized in the following reaction scheme:

$$
\begin{aligned}
& \begin{array}{c}
\mathrm{La}^{3+}(\mathrm{aq})+\mathrm{SO}_{4}{ }^{2-}(\mathrm{aq}) \stackrel{K_{1}}{\leftrightarrow} \\
\text { fully hydrated ions }
\end{array} \\
& \begin{array}{c}
\mathrm{La}^{3+}\left(\mathrm{OH}_{2}\right)_{2} \mathrm{SO}_{4}{ }^{2-} \\
\text { outer-outer-sphere c }
\end{array} \\
& \qquad \mathrm{La}^{3+}\left(\mathrm{OH}_{2}\right) \mathrm{SO}_{4}{ }^{2-} \text { outer-sphere c } \stackrel{K_{3}}{\leftrightarrow} \\
& \begin{array}{l}
\mathrm{La}^{3+} \mathrm{OSO}_{3}{ }^{2-} \\
\text { inner-sphere c }
\end{array}
\end{aligned}
$$

where $K_{i}(i=1$ to 3$)$ are the 'stepwise' constants for the corresponding equilibria. The first equilibrium step is the diffusion controlled step and defined as:

$$
K_{1}=\frac{\left[\mathrm{La}^{3+}\left(\mathrm{OH}_{2}\right)_{2} \mathrm{SO}_{4}{ }^{2-}\right]}{\left[\mathrm{La}^{3+}(\mathrm{aq})\right] \times\left[\mathrm{SO}_{4}{ }^{2-}(\mathrm{aq})\right]}
$$

the second step, the intermediate step, resulting in outer-sphere complex is defined as:

$$
K_{2}=\frac{\left[\mathrm{La}^{3+}\left(\mathrm{OH}_{2}\right) \mathrm{SO}_{4}{ }^{2-}\right]}{\left[\mathrm{La}^{3+}\left(\mathrm{OH}_{2}\right)_{2} \mathrm{SO}_{4}{ }^{2-}\right]}
$$

and the third step, the rate determining step, is defined as:

$$
K_{3}=\frac{\left[\mathrm{La}^{3+} \mathrm{OSO}_{3}{ }^{2-}\right]}{\left[\mathrm{La}^{3+}\left(\mathrm{OH}_{2}\right) \mathrm{SO}_{4}{ }^{2-}\right]} .
$$

(The rate constants of the forward and backward reaction, the rate determining step via $\mathrm{La}^{3+}\left(\mathrm{OH}_{2}\right) \mathrm{SO}_{4}{ }^{2-} \leftrightarrow \mathrm{La}^{3+} \mathrm{OSO}_{3}{ }^{2-}+$ $\mathrm{H}_{2} \mathrm{O}$, may be formulated via $K_{3}=k_{\mathrm{f}} / k_{\mathrm{b}}$. The rate constants for forward $\left(k_{\mathrm{f}}\right)$ and backward $\left(k_{\mathrm{b}}\right)$ reactions were published from earlier ultrasound absorption measurements. ${ }^{19,20,34,35}$ )

The overall association constant, $K_{\mathrm{A}}$, as measured by traditional techniques such as potentiometry or conductivity, corresponds to the equilibrium:

$$
\mathrm{La}^{3+}(\mathrm{aq})+\mathrm{SO}_{4}{ }^{2-}(\mathrm{aq}) \leftrightarrow \mathrm{LaSO}_{4}{ }^{+}(\mathrm{aq})
$$

where $\mathrm{LaSO}_{4}{ }^{+}(\mathrm{aq})$ refers to all forms of associated $\left\{\mathrm{La}^{3+}, \mathrm{SO}_{4}{ }^{2-}\right\}$ species of $1: 1$ stoichiometry in aqueous solution (thermodynamics makes no distinction between dissolved species of identical stoichiometry but with differing levels of hydra$\left.\operatorname{tion}^{24,28}\right)$. The $K_{\mathrm{A}}$ value, the overall association constant for the three step mechanism is related to the individual $K_{i}$ values via eqn (14):

$$
K_{\mathrm{A}}=K_{1}+K_{1} K_{2}+K_{1} K_{2} K_{3}
$$

Three $K_{i}$ values were obtained from ultrasound absorption (UA) experiments ${ }^{19,20}$ namely $K_{1}=435, K_{2}=1.96$ and $K_{3}=3.7$. The reported $K_{\mathrm{A}}$ value, 4200 , derived from UA is too large compared with the recommended $K_{\mathrm{A}}$ value at 3620 at $25{ }^{\circ} \mathrm{C} .{ }^{36-38}$

The $\nu_{1}-\mathrm{SO}_{4}{ }^{2-}$ band can be fitted with three band components, a component of the 'free' $\mathrm{SO}_{4}{ }^{2-}$ (aq) band at $\sim 980 \mathrm{~cm}^{-1}$, a component at $983 \mathrm{~cm}^{-1}$ representing the $\mathrm{SO}_{4}{ }^{2-}$ in the outersphere-complex and the mode of the sulfato-complex at 991 $\mathrm{cm}^{-1}$ (Fig. 6B). The sulfato-complex band is quite distinct, while the band of the outer sphere complex is severely overlapped by the $\mathrm{SO}_{4}{ }^{2-}$ (aq) band at $980 \mathrm{~cm}^{-1}$. The $\mathrm{SO}_{4}{ }^{2-}$ band of the outerouter-sphere complex is not distinguishable from the band of the free sulfate.

The degree of the sulfato-complex formation $\alpha$, represents the spectroscopically-determined fraction of sulfate present as 


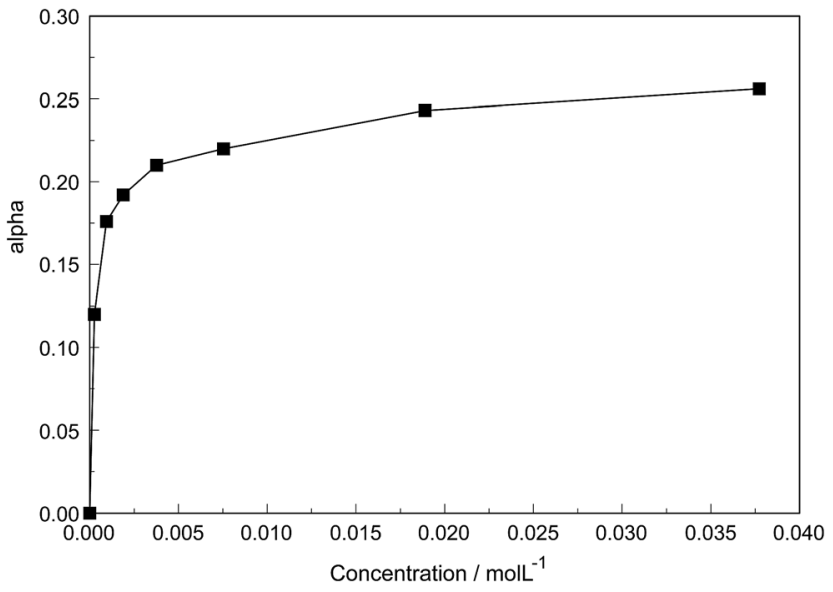

Fig. 8 Degree of sulfato complex-formation, $\alpha$, as a function of the stoichiometric $\mathrm{La}_{2}\left(\mathrm{SO}_{4}\right)_{3}$ concentration at $23^{\circ} \mathrm{C}$.

sulfato complex according to eqn (8). Fig. 8 shows the present quantitative Raman results as a function of the stoichiometric solute concentration $C_{0}$. The proportion of the inner-sphere complex formed appears almost insensitive to the concentration $>0.003 \mathrm{~mol} \mathrm{~L}^{-1}$ but below this concentration vanishes more severely. This paradox can be resolved if it is assumed that the inner-sphere complex, $\left[\mathrm{LaOSO}_{3}\right]^{+}$is in equilibrium with the outer-sphere complex, $\left[\mathrm{La}\left(\mathrm{OH}_{2}\right) \mathrm{SO}_{4}\right]^{+}$and not with the "free" sulfate. The Raman spectroscopically determined $K_{3}$ value was determined according to eqn (12). In Table S1 (ESI $\dagger$ ) the data of the analytical curve fitting on the $\nu_{1}-\mathrm{SO}_{4}{ }^{2-}$ band profile of the two band components at $981 \mathrm{~cm}^{-1}$ and $991.1 \mathrm{~cm}^{-1}$ are given such as integrated band intensities, $A_{981}$ and $A_{991}$, as well as the degree of sulfato-complex formation of the equilibrium between the outer-sphere complex and the inner-sphere-sulfato complex. From these data a $K_{3}$-value was determined at $0.90 \pm$ 0.1 at $23{ }^{\circ} \mathrm{C}$ and it appears that the Raman derived $K_{3}$ value is comparable to the UA-values considering the uncertainty of the data from the UA measurements. ${ }^{19,20,34,35}$

Temperature dependent measurements. A $0.0094 \mathrm{~mol} \mathrm{~L}^{-1}$ $\mathrm{La}_{2}\left(\mathrm{SO}_{4}\right)_{3}$ solution was measured from 23 to $98{ }^{\circ} \mathrm{C}$ and the temperature dependent isotropic scattering profiles are given in Fig. 9. Generally, the peak position of the $\nu_{1}-\mathrm{SO}_{4}{ }^{2-}$ band complex shifts to slightly lower wavenumbers with temperature increase. The band of "free" sulfate at $23^{\circ} \mathrm{C}$ peaks at $981.0 \mathrm{~cm}^{-1}$ and shifts to $976.5 \mathrm{~cm}^{-1}$ at $98{ }^{\circ} \mathrm{C}$. A similar peak shift was observed for the band of the coordinated sulfate which peaked at $991 \mathrm{~cm}^{-1}$ at $23{ }^{\circ} \mathrm{C}$ and shifts to $987 \mathrm{~cm}^{-1}$ at $98{ }^{\circ} \mathrm{C}$. Furthermore, the band complex (and the band components) broadens with temperature. In addition to these two already resolved band components a third band component assigned to sulfate of the outer-sphere ion pair, $\mathrm{La}^{3+}\left(\mathrm{H}_{2} \mathrm{O}\right) \mathrm{SO}_{4}{ }^{2-}$ was detected at $983 \mathrm{~cm}^{-1}$ at $23{ }^{\circ} \mathrm{C}$ which shifted to $978.6 \mathrm{~cm}^{-1}$ at $98{ }^{\circ} \mathrm{C}$. The results of a three component band fit on the $\nu_{1}-\mathrm{SO}_{4}{ }^{2-}$ band complex are given in Table S2 (ESI†). The most striking fact, however, is the rise of the band component of the coordinated sulfate band, the so called bound sulfate, and the degree of

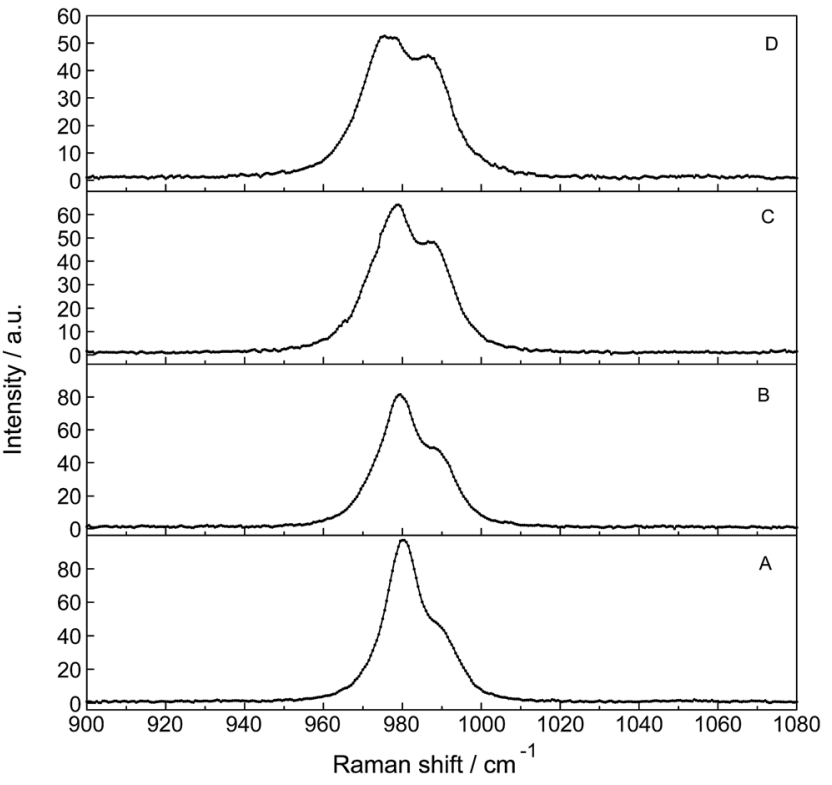

Fig. 9 Temperature dependence of a series of isotropic Raman scattering profiles of a $0.0093 \mathrm{~mol} \mathrm{~L} \mathrm{~L}^{-1} \mathrm{La}_{2}\left(\mathrm{SO}_{4}\right)_{3}$ solution in the wavenumber range from $900-1080 \mathrm{~cm}^{-1}\left(\nu_{1} \mathrm{SO}_{4}{ }^{2-}\right.$ stretching region). From bottom to top: $24.0^{\circ} \mathrm{C}, 50.0^{\circ} \mathrm{C}, 75.0^{\circ} \mathrm{C}$ and $98.0^{\circ} \mathrm{C}$. Note that with temperature increase the bands at $980.3 \mathrm{~cm}^{-1}$ of "free" $\mathrm{SO}_{4}{ }^{2-}$ (aq) and coordinated $\mathrm{SO}_{4}{ }^{2-}$ at $991 \mathrm{~cm}^{-1}$ shift slightly to lower wavenumbers. The intensity of the band at $980.5 \mathrm{~cm}^{-1}$ of "free" $\mathrm{SO}_{4}{ }^{2-}(\mathrm{aq})$, however, decreases markedly with the rise in temperature while the intensity of band of the complex bound sulfate at $991 \mathrm{~cm}^{-1}$ increases considerably. At $24{ }^{\circ} \mathrm{C} \sim 25 \%$ of the sulfate occurs in the $\mathrm{La}^{3+}$-sulfato complex species while at $98.0{ }^{\circ} \mathrm{C} \sim 42 \%$ of the sulfate is bound as a sulfato-complex.

sulfato-complex formation rises from 0.25 at $23{ }^{\circ} \mathrm{C}$ to 0.42 at $98{ }^{\circ} \mathrm{C}$.

The increase of the $\mathrm{La}^{3+}$-sulfato complex with enhancing temperature shows that the rate determining third step of reaction (10) is an endothermic process by which heat is absorbed, making the enthalpy change positive. The change of the equilibrium constant as a function of temperature follows the equation:

$$
\ln \left(K_{3}\right)=-\frac{\Delta H^{0}}{R T}+\frac{\Delta S^{0}}{R}
$$

Plotting $\ln K_{3}$ as a function of $1 / T$ and assuming that the change of the heat capacity in this small temperature range is zero leads to the enthalpy and the entropy of the last step of the sulfato-complex formation, the outer-sphere, inner-sphere sulfato complex formation according to $\mathrm{La}^{3+}\left(\mathrm{OH}_{2}\right) \mathrm{SO}_{4}{ }^{2-} \leftrightarrow$ $\mathrm{La}^{3+} \mathrm{OSO}_{3}{ }^{2-}$. The following quantitative results were derived from the temperature-dependence of $\ln \left(K_{3}\right)$ as a function of the reciprocal temperature (in Kelvin): $\Delta H^{0}=18.6 \mathrm{~kJ} \mathrm{~mol}^{-1}$ and $\Delta S^{0}$ $=62.1 \mathrm{~J} \mathrm{~mol}^{-1} \mathrm{~K}^{-1}$. The enthalpy for the rate determining step of eqn (9) compares favorably with the extrapolated value, $15 \mathrm{~kJ}$ $\mathrm{mol}^{-1}$, for $\Delta H^{0}$ taken from ref. 39 .

Finally, it should be mentioned that Malatesta and coworkers $^{40}$ showed, by comparing activity coefficient data on 
$\mathrm{La}_{2}\left(\mathrm{SO}_{4}\right)_{3}(\mathrm{aq})$ and $\mathrm{La}\left(\mathrm{ClO}_{4}\right)_{3}(\mathrm{aq})$, that in the sulfate system of $\mathrm{La}^{3+}$ "there is evidence of short-range interactions that add to long-range interactions for lanthanum and bivalent metal sulfates, as if sulfate ions were displacing water from the hydration shells of the cations". This is exactly what the Raman spectroscopic data show.

\section{Conclusions}

Raman spectroscopic measurements have been made of aqueous solutions of $\mathrm{La}\left(\mathrm{ClO}_{4}\right)_{3}, \mathrm{La}_{2}\left(\mathrm{SO}_{4}\right)_{3}$, and $\mathrm{Na}_{2} \mathrm{SO}_{4}$ in water and heavy water, in the terahertz frequency region (40-1400 $\mathrm{cm}^{-1}$ ) and down to low concentrations $\left(0.000263 \mathrm{~mol} \mathrm{~L}^{-1}\right)$. Temperature dependent measurements have been carried out on a $0.0098 \mathrm{~mol} \mathrm{~L}^{-1} \mathrm{La}_{2}\left(\mathrm{SO}_{4}\right)_{3}$ solution from $23-98{ }^{\circ} \mathrm{C}$. In solutions of $\mathrm{La}\left(\mathrm{ClO}_{4}\right)_{3}$ with water and heavy water, the $\left[\mathrm{La}\left(\mathrm{OH}_{2}\right)_{9}\right]^{3+}$ and $\left[\mathrm{La}\left(\mathrm{OD}_{2}\right)_{9}\right]^{3+}$ have been characterized and a weak, strongly polarized band observed at $343 \mathrm{~cm}^{-1}$ and 326 $\mathrm{cm}^{-1}$ respectively assigned to the $\nu_{1} \mathrm{LaO}_{9}$ mode, the breathing mode of the clusters. The Raman spectroscopic data suggest that the $\left[\mathrm{La}\left(\mathrm{OH}_{2}\right)_{9}\right]^{3+}$ ion is thermodynamically stable in dilute perchlorate. No inner-sphere complexes in these dilute solutions could be detected spectroscopically.

In $\mathrm{La}_{2}\left(\mathrm{SO}_{4}\right)_{3}(\mathrm{aq})$, in addition to the $\nu_{1}-\mathrm{SO}_{4}{ }^{2-}$ mode at 980 $\mathrm{cm}^{-1}$, a pronounced band component at $991 \mathrm{~cm}^{-1}$ has been assigned to an inner-sphere complex (ISC). The sulfate is most likely bound as a monodentate ligand ([ $\left.\left.\mathrm{LaOSO}_{3}\right]^{+}\right)$. Conformation of this assignment is provided by the component at 312 $\mathrm{cm}^{-1}$ of the $\left[\mathrm{La}\left(\mathrm{OH}_{2}\right)_{8} \mathrm{OSO}_{3}\right]^{+}$unit in addition to the band at 343 $\mathrm{cm}^{-1}$ for the fully hydrated cluster, $\left[\mathrm{La}\left(\mathrm{OH}_{2}\right)_{9}\right]^{3+}$. A similar $\nu_{1^{-}}$ $\mathrm{SO}_{4}{ }^{2-}$ band contour has been observed in $\mathrm{La}_{2}\left(\mathrm{SO}_{4}\right)_{3}$ solutions in heavy water. After subtraction of the component of the ISC at $991 \mathrm{~cm}^{-1}$, the $\nu_{1}-\mathrm{SO}_{4}{ }^{2-}$ band in $\mathrm{La}_{2}\left(\mathrm{SO}_{4}\right)_{3}(\mathrm{aq})$ showed systematic differences from that in $\left(\mathrm{NH}_{4}\right)_{2} \mathrm{SO}_{4}(\mathrm{aq})$ and dilute $\mathrm{Na}_{2} \mathrm{SO}_{4}(\mathrm{aq})$. This is consistent with a $\nu_{1}-\mathrm{SO}_{4}{ }^{2-}$ band at $983.3 \mathrm{~cm}^{-1}$ that can be assigned to the existence of an outer-sphere complex ion (OSCs). The band profile of the weaker antisymmetric S-O stretching mode, $\nu_{3}-\mathrm{SO}_{4}{ }^{2-}$ shows asymmetry and has been fitted with four band components including the component of the "free" $\nu_{3}-\mathrm{SO}_{4}{ }^{2-}$ band reinforcing the existence of the ligated sulfate. In aqueous $\mathrm{La}_{2}\left(\mathrm{SO}_{4}\right)_{3}$ solutions thermodynamically stable ISC have been detected down to very low concentrations at $0.00026 \mathrm{~mol} \mathrm{~L}^{-1}$ and in addition an OSC, $\left[\mathrm{La}\left(\mathrm{OH}_{2}\right) \mathrm{SO}_{4}\right]^{+}$and the free non-ligated sulfate. The observed change of the equilibrium concentration of the ISC, $\left[\left(\mathrm{LaOSO}_{3}\right)\right]^{+}$with dilution reflects the stepwise sulfato-complex formation. A $K_{3}$-value has been determined at $\sim 0.9$ of the equilibrium between OSC and ISC.

Temperature dependent measurements $\left(23-98{ }^{\circ} \mathrm{C}\right)$ on a $0.0098 \mathrm{~mol} \mathrm{~L}^{-1} \mathrm{La}_{2}\left(\mathrm{SO}_{4}\right)_{3}$ solution has shown that the concentration of the $\mathrm{La}^{3+}$ sulfato-complex rises with increasing temperature while at the same time the concentration of the "free" sulfate diminished. The sulfato-complex formation is an endothermic process absorbing heat with increasing temperature. The following thermodynamic parameters for the rate determining equilibrium, $\left[\mathrm{La}\left(\mathrm{OH}_{2}\right) \mathrm{SO}_{4}\right]^{+} \leftrightarrow\left[\mathrm{LaOSO}_{3}\right]^{+}+\mathrm{H}_{2} \mathrm{O}$, has been determined: $\Delta H^{0}=18.6 \mathrm{~kJ} \mathrm{~mol}^{-1}$ and $\Delta S^{0}=62.1 \mathrm{~J}$ $\mathrm{mol}^{-1} \mathrm{~K}^{-1}$.

\section{References}

1 R. A. Vanderpool, M. A. Khan and R. Frech, J. Mol. Struct., 1991, 245, 255-273.

2 M. H. Choi, M. K. Kim, V. Jo, D. W. Lee, I. W. Shim and K. M. Ok, Bull. Korean Chem. Soc., 2010, 31, 1077-1080.

3 M. S. Wickleder, Chem. Rev., 2002, 102, 2011-2087.

4 W. W. Rudolph and G. Irmer, Dalton Trans., 2015, 44, 295305, DOI: 10.1039/c4dt03003f.

5 J. Näslund, P. Lindqvist-Reis, I. Persson and M. Sandström, Inorg. Chem., 2000, 39, 4006-4011.

6 I. Persson, P. D'Angelo, S. de Panfilis, M. Sandström and L. Eriksson, Chem.-Eur. J., 2008, 14, 3056-3066.

7 W. W. Rudolph, D. Fischer, G. Irmer and C. C. Pye, Proceedings of the XXI International Conference on Raman Spectroscopy, ed. R. Whithnall and B. Z. Chowdhry, IM Publications, Charlton, Chichester, 2008, pp. 672-673.

8 W. W. Rudolph, R. Mason and C. C. Pye, Phys. Chem. Chem. Phys., 2000, 2, 5030-5040.

9 W. W. Rudolph and G. Irmer, Dalton Trans., 2013, 39193935.

10 W. W. Rudolph and G. Irmer, Dalton Trans., 2013, 1446014472.

11 W. W. Rudolph and C. C. Pye, Phys. Chem. Chem. Phys., 2002, 4, 4319-4327.

12 W. W. Rudolph, D. Fischer, M. R. Tomney and C. C. Pye, Phys. Chem. Chem. Phys., 2004, 6, 5145-5155.

13 A. I. Vogel, A Text-Book of Quantitative Inorganic Analysis, Longman, London, 3rd edn, 1961.

14 F. H. Spedding, M. J. Pikal and B. O. Ayers, J. Phys. Chem., 1966, 70, 2440-2449; see p. 2441.

15 W. W. Rudolph and G. Irmer, Appl. Spectrosc., 2007, 61, 1312-1327.

16 W. W. Rudolph, D. Fischer and G. Irmer, Appl. Spectrosc., 2006, 60, 130.

17 W. W. Rudolph, J. Chem. Soc., Faraday Trans., 1998, 94, 489499.

18 W. W. Rudolph, Z. Phys. Chem., 1996, 194, 73-95.

19 D. P. Fay, D. Litchinsky and N. Purdie, J. Phys. Chem., 1969, 73, 544-552.

20 N. Purdie and C. A. Vincent, Trans. Faraday Soc., 1967, 63, 2745-2757.

21 L. Helm and A. E. Merbach, Chem. Rev., 2005, 105, 19231959.

22 G. E. Walrafen, J. Chem. Phys., 1962, 36, 1035-1042.

23 H. Kanno, J. Alloys Compd., 1993, 192, 271-273.

24 W. W. Rudolph, G. Irmer and G. Hefter, Phys. Chem. Chem. Phys., 2003, 5, 5253-5261.

25 R. Buchner, S. G. Capewell, G. Hefter and P. M. May, J. Phys. Chem. B, 1999, 103, 1185-1192.

26 W. W. Rudolph and G. Irmer, Appl. Spectrosc., 2007, 61, 1312-1327.

27 M. H. Brooker, G. Hancock, B. C. Rice and J. Shapter, J. Raman Spectrosc., 1989, 20, 683-694. 
28 R. Buchner, W. W. Rudolph and G. Hefter, J. Chem. Phys., 2005, 123, 034508; J. Chem. Phys., 2006, 124, 247101.

29 C. F. Baes and R. E. Mesmer, The Hydrolysis of Cations, WileyInterscience, New York, 1976.

30 G. D. Klungness and R. H. Byrne, Polyhedron, 2000, 19, 99107.

31 A. Stefasson, Environ. Sci. Technol., 2007, 41, 6117-6123.

32 M. Eigen and K. Tamm, Z. Elektrochem., 1962, 66, 93-107.

33 M. Eigen and K. Tamm, Z. Elektrochem., 1962, 66, 107-121.

34 J. Reidler and H. B. Silber, J. Phys. Chem., 1973, 77, 12751280.
35 B. Voleišienè, G. Miglinienè and A. Voleišis, J. Acoust. Soc. Am., 1999, 105, 962.

36 S. A. Wood, Chem. Geol., 1990, 82, 159-186.

37 S. A. Wood, Chem. Geol., 1990, 88, 99-125.

38 J. Schijf and R. H. Byrne, Geochim. Cosmochim. Acta, 2004, 68, 2825-2837.

39 D. P. Fay and N. Purdie, J. Phys. Chem., 1970, 74, 1160-1166. 40 F. Malatesta, F. Bruni and N. Fanelli, Phys. Chem. Chem. Phys., 2002, 4, 121-126. 